\title{
Accelerated heterologous prime-boost adenovirus vector-based SIV vaccine in neonatal rhesus monkeys
}

\author{
J Liu*, H Li, M lampietro, DH Barouch \\ From AIDS Vaccine 2012 \\ Boston, MA, USA. 9-12 September 2012
}

\section{Background}

A pediatric HIV-1 vaccine is required to protect infants against HIV-1 transmission from breastfeeding. Such a vaccine would need to induce protective immunity at mucosal surfaces in neonates as soon as possible after birth. Recombinant adenovirus (rAd) vectors have been shown to elicit potent systemic and mucosal virus-specific immune responses in adult non-human primates and humans but have not previously been studied in detail in infants.

\section{Methods}

Newborn rhesus monkeys were injected intramuscular (i.m.) with $10^{\wedge} 11$ viral particles of rAd serotype 26 or 35 vectors expressing SIVmac239 Gag. Peripheral blood was collected to determine systemic Gag-specific cellular and humoral immune responses. At week 52, peripheral lymph nodes, bronchoalveolar lavage (BAL) and pinch biopsies of colorectal, duodenal and oral cavity mucosa were collected to evaluate mucosal Gag-specific $\mathrm{T}$ lymphocyte responses.

\section{Results}

A single injection of rAd26 encoding SIVmac239 Gag in rhesus monkeys on the day of birth elicited detectable SIV-specific cellular immune responses, but these responses were transient and waned quickly. In contrast, an accelerated heterologous prime-boost regimen involving administration of rAd35 at birth and rAd26 at 4 weeks of life elicited potent and durable Gag-specific cellular and humoral immune responses in neonatal rhesus monkeys, including mucosal responses that remained detectable at one year of age.

\footnotetext{
Beth Israel Deaconess Medical Center, Harvard Medical School, Boston, MA,
} USA

(c) 2012 Liu et al; licensee BioMed Central Ltd. This is an Open Access article distributed under the terms of the Creative Commons

\section{Conclusion}

These results suggest the potential of an accelerated heterologous rAd prime-boost regimen as a candidate neonatal HIV-1 vaccine in newborns.

Published: 13 September 2012

doi:10.1186/1742-4690-9-S2-O48

Cite this article as: Liu et al:: Accelerated heterologous prime-boost adenovirus vector-based SIV vaccine in neonatal rhesus monkeys.

Retrovirology 2012 9(Suppl 2):O48.
Submit your next manuscript to BioMed Central and take full advantage of:

- Convenient online submission

- Thorough peer review

- No space constraints or color figure charges

- Immediate publication on acceptance

- Inclusion in PubMed, CAS, Scopus and Google Scholar

- Research which is freely available for redistribution

Submit your manuscript at www.biomedcentral.com/submit
( Biomed Central 